症例

2 期的手術で治癒せしめた慢性腎不全合併食道気管支瘦の 1 例

\begin{tabular}{llllllllll}
\multicolumn{10}{c}{ 横浜市立大学第 2 外科 } \\
森 & 脇 & 義 & 弘 & 国 & 崎 & 主 税 & 上 & 倫 & 夫 \\
秋 & 山 & 浩 & 利 & 龟 & 田 & 久仁郎 & 嵦 & 田 & 紘
\end{tabular}

維持透析中の慢性腎不全患者で, 食道破裂, 繸隔炎から食道気管支摟を形成した症例 に対して，2 期的手術を選択し救命し得たので報告する. 症例は，1990 年から人工透析 を導入している 55 歳, 女性. 1995 年 3 月 7 日, 上部消化管内視鏡検查後の食道破裂およ び縦隔炎のため保存的治療を受けていたが，6月から食道気管支瘦が明らかとなり当科

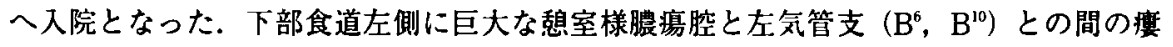
孔を認めたが，炎症反応，低栄養状態，心機能，呼吸機能低下など全身状態不良であっ たため, 高カロリー輸夜を併用した経腸栄養, 輸血により全身状態改善を図り，手術は 2 期的に行った. 初回手術は 1995 年 9 月 19 日, 左第 7 助間開胸による胸部食道抜去, 頚 部食道捙, 胃瘦造設術, 膿瘍腔内腔からの縫合閉鎖, 生体用接着郕による接着被覆, 再 建手術は11月 21 日（初回手術後63病日）, 覀全胃管を用いた胸骨後経路による再建術 を施行した，術後経過は良好で，再建手術後第 37 病日軽快退院となった.

索引用語：食道気管支掼, 慢性腎不全, 2 期的手術

粕言

慢性腎不全の人工腎透析患者に対する観血的手術 は, 周術期の透析や手術のタイミングの決定, 術式の 選択, 術後の管理が容易とはいえない口。一方, 食道破 裂は，手術のタイミングが困難で，診断治療の遅れか ら術後維隔炎，胸膜炎を併発し予後不良となる ${ }^{2}$. 今 回，呼吸機能低下，心機能低下を伴った維持透析中の 慢性腎不全患者で,内視鏡検査を契機とした食道破裂， 縦隔炎から食道気管支度を形成した症例に対して，2 期的再建術を選択し, 救命し得たので報告する.

\section{症 例}

患者：55 歳, 女性.

既往歴：慢性系球体腎炎による慢性腎不全のため。 1990 年から人工透析が施行されている.

現病歴：1995年 3 月 7 日,スクリーニング検査の目 的で上部消化管の内視鏡検査を行った.内視鏡挿入時, 抜去時には異常は認めなかったが、検查中に嘔吐が頻 回にみられた，その後から胸背部痛, 発熱が出現し, 胸部単純 X 線検查上, 縦隔気腫が認められた，頻回の 嘔吐による食道破裂および縦隔炎と診断され, 絶飲食,

1998 年 10 月 26 日受付 1999 年 4 月 2 日探用
抗生郕投与などの保存的治療を受けていた. しかし, 6 月 28 日の食道造影で食道気管支瘦が明らかとなっ たため, 1995 年 8 月 24 日, 治療目的のために当科へ入 院となった。

入院時現症: 白血球数は $9.700 / \mathrm{mm}^{3}$ と正常範囲内 であったが, CRP は $2.4 \mathrm{mg} / \mathrm{dl}$ と上昇し,軽度の炎症反 応を認めた。岩佐の nutritional assessment index ${ }^{3 /}$ 38.9 と低值であった。 心電図では上室性期外収綟, 心工 コー検査上左室肥大と心拍出量の低下 $(53.1 \%)$ を認 め, 呼吸機能検查でも\%VC が $70.6 \%$ と拘束性障害, 動 脈血血液ガス分析でも低酸素血症を認めるなど, 全身 状態は不良であった（表 1 ).

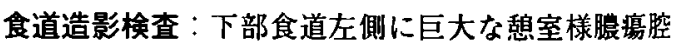
と左気管支 $\mathrm{B}^{6} お よ ひ ゙ \mathrm{~B}^{10}$ との間の㾇孔を認めたが, 分 泌物と思われる陰影は認められなかった（図 1).

食道内視鏡検查：秝室様膿瘍腔の壁は薄く, 肺実質 が透見できた（図 2)，膿場腔内に気管支分泌物は認め られなかった。

胸部 computed tomography (CT) 険查 : 秝室様樶 場腔は，胸部下行大動脈の前面を覆うように広がり，

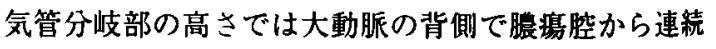
した度孔を認めた（图3）。 
表 1 入院時, 初回手術前，再㲧手術前の検查値

\begin{tabular}{|c|c|c|c|}
\hline & 入院時 & 初回手術前 & 再建手術前 \\
\hline WBC $\left(\mathrm{mm}^{3}\right)$ & 9.700 & 13,000 & 14,100 \\
\hline $\mathrm{Hb}(\mathrm{g} / \mathrm{dl})$ & 8.0 & 11.8 & 10.3 \\
\hline Hct $(\%)$ & 23.2 & 34.5 & 31.4 \\
\hline Plt $\left(\times 10^{4} / \mathrm{mm}^{3}\right)$ & 3.1 & 19.2 & 30.6 \\
\hline $\mathrm{FBS}(\mathrm{mg} / \mathrm{dl})$ & 118 & 139 & 115 \\
\hline $\mathrm{CRP}(\mathrm{mg} / \mathrm{dl})$ & 2.4 & 0.9 & 1.0 \\
\hline PT & 1.16 & 1.10 & 0.73 \\
\hline APTT & 26.4 & 26.6 & 23.3 \\
\hline $\mathrm{TP}(\mathrm{g} / \mathrm{dl})$ & 5.2 & 6.5 & 6.5 \\
\hline ALB $(g d l)$ & 3.0 & 3.5 & 3.6 \\
\hline BLN (mg/dl) & 35 & 38 & 52 \\
\hline CREAT $(\mathrm{mg} \mathrm{d})$ & 7.55 & 3.22 & 4.15 \\
\hline GOT (IU' $l)$ & 17 & 35 & 11 \\
\hline GPT (IU $l)$ & 8 & 22 & 8 \\
\hline ALP (IL' $l)$ & 232 & 310 & 195 \\
\hline LDH (IU $l$ ) & 539 & 572 & 237 \\
\hline T. bil (mg/dl) & 0.2 & 0.2 & 0.2 \\
\hline \multicolumn{4}{|c|}{ arterial blood gas analysis $\left(\mathrm{Fi} \mathrm{O}_{2}=0.21\right)$} \\
\hline $\mathrm{PaO}_{2}$ & 104.6 & 70.5 & 79.4 \\
\hline $\mathrm{PaCO}_{2}$ & 26.6 & 44.6 & 46.3 \\
\hline \multicolumn{4}{|l|}{ 入院時 } \\
\hline 心機能 (エコー) & \multicolumn{3}{|c|}{$\mathrm{EF}: 53.1^{\circ}$} \\
\hline 呼吸機能 & $\begin{array}{l}\mathrm{CI}: 2.771 \\
{ }_{0} \mathrm{VVC}: 70 \\
{ }_{0} \mathrm{FEV} \\
\mathrm{MMV}: 2 \\
\mathrm{~V}_{\mathrm{S}}: 0.70 l\end{array}$ & $\begin{array}{l}n / \\
5 \% \\
\sec \\
c\end{array}$ & \\
\hline
\end{tabular}

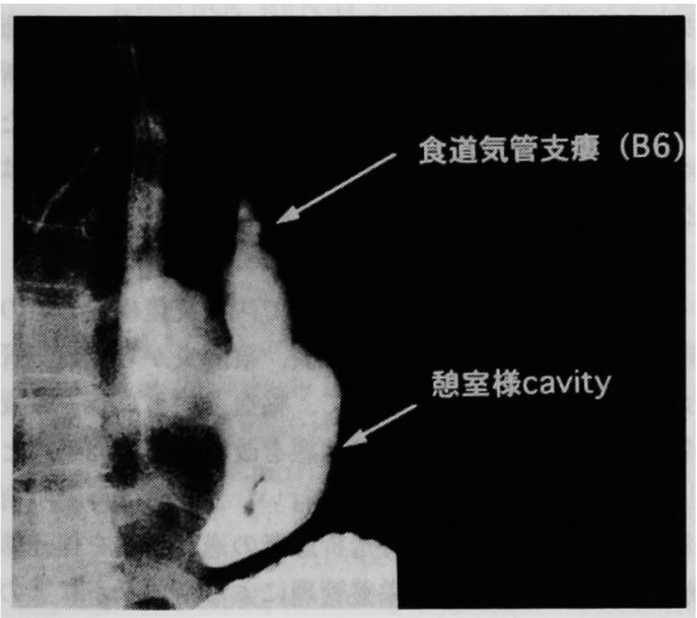

图 1 上部消化管造影検查所見

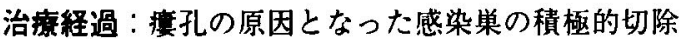
が必要と考えたが，慢性腎不全，呼吸機能低下，低栄 盖などを合併し， Saitoら"の organ function index

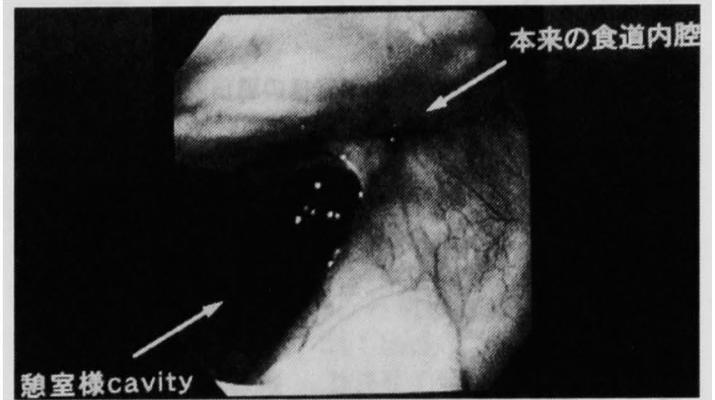

図 2 上部消化管内視鏡検植所見

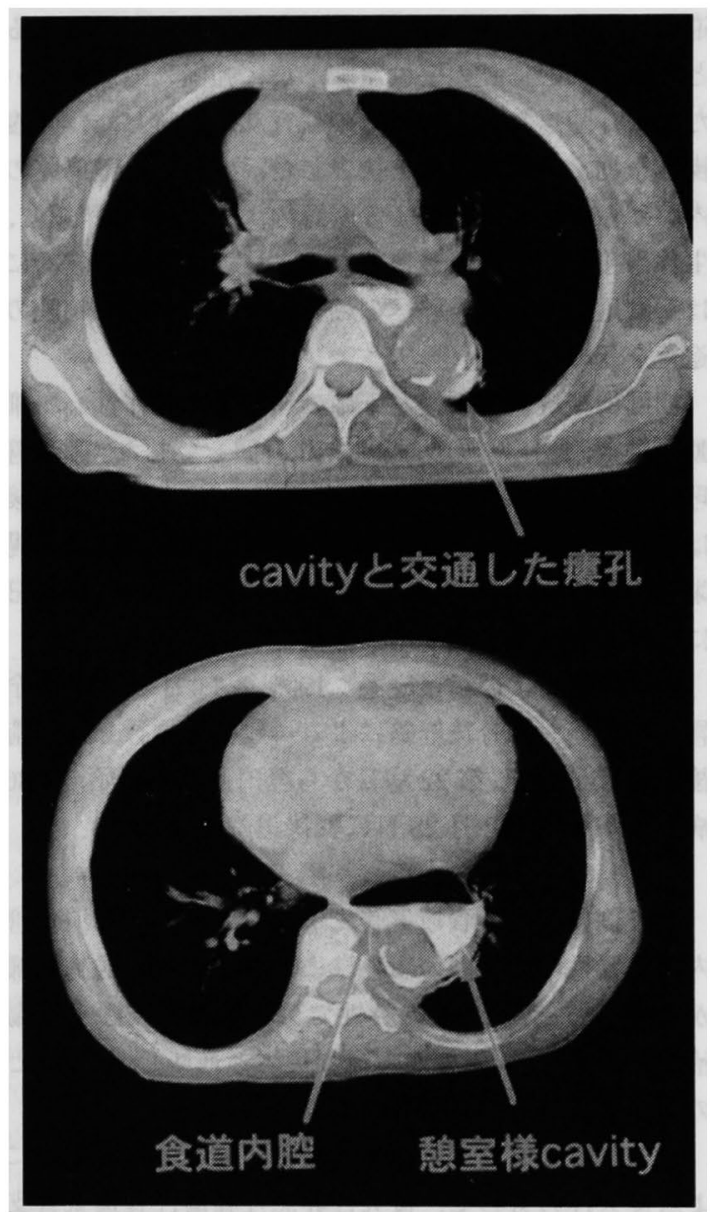

図 3 腹部 CT 検查所見

(OFI) が 0.459 と術死率 $50 \%$ 以上の high risk 群にな るため，高カロリー輸液 $(1,000 \mathrm{Cal} /$ 日)を併用した経 腸栄養 $(1,200 \mathrm{Cal} /$ 日) と輸血により全身状態改善を図 り，手術は 2 期的分割手術を行うこととした。

初回手術：1995 年 9 月 19 日, 胸部食道抜去, 頸部食 


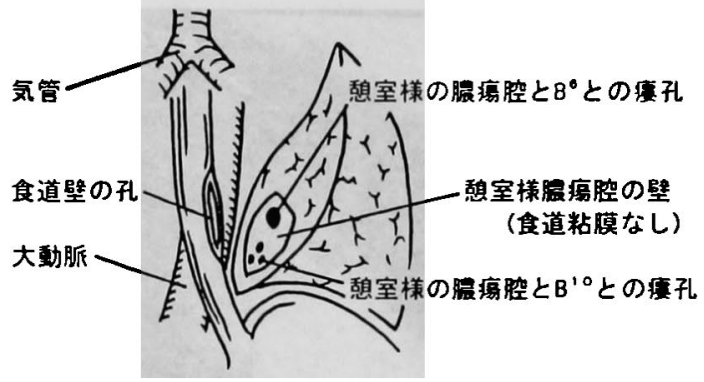

図 4 初回手術時所見（賏室様膿瘍腔の壁を食道壁と の移行部で切離した後)

道瘦，胃倎造設術を施行した．左第 7 肋間で開胸する

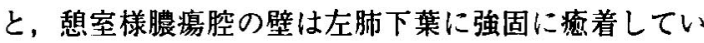
たため，膿瘍腔を食道壁との移行部で切離した，開腹 操作を加え，胸部食道を抜去した．残存した膿瘍腔の 内腔から摜孔入口部を 4 力所認め,これを䋖合閉鎖し， 生体用接着剂で接着被覆した(図 4)。病理組織学的に は，食道壁から膿瘍腔への移行部で筋層および粘膜の 途絶を認めた。

初回術後経過：術後左下肺の無気肺, 発作性心房細 動が続き，陽圧呼吸の離脱に14 日間を要した。栄養管 理は, 輸液量は1日 $800 \mathrm{ml}(21 \mathrm{ml} / \mathrm{kg})$ とし, 術直後 は経静脈的に $1.000 \mathrm{Cal} /$ 日，術後第 4 病日以降は経腸 栄盖も併用し $1,400 \mathrm{Cal} /$ 日とした。初回手術後 63 病日 に再建手術（第 2 回手術）を施行した。

再建手術および術後経過：1995 年11月21 日, 垔全 胃管を用いた胸骨後経路による再建術を施行した。術 後経過は良好で, 第 22 病日から経口搨取を開始, 第 36 病日の 1995 年 12 月 28 日に軽快退院となった。

\section{考察}

自験例における食道気管支瘦の成因は，上部消化管 内視鏡操作中の頻回の嘔吐により食道の生理的脆弱部 が破裂 $L^{5)}$ ，透析患者の特性である組織脆弱性や創傷 治瘜の遷延 ${ }^{61}$ ，低栄養から縦隔炎へと進展し, 気管支と の間に瘦孔を形成したものと考えられた。

食道気管支瘻は，その多くが食道癌など悪性腫瘍に よる後天性のもので, 後天性非悪性腫瘍性食道気管支 瘦は，先天性食道気管支瘻とならんで，非常にまれな 疾患である7．著者らの検索しえた範囲で，最近 10 年 間の本邦報告例は自験例を含め 8 例 $^{\mid>-15 !}$ あ，男女比 は $3: 5$, 年龊は 47 歳から 73 歳, 平均 62 歳であった。 4 例に憩室合併があり，食道破裂部位は中部食道が 6 例 $(75 \%)$ と大部分を占めた.

腎不全患者の手術の危険因子に関しては，横田ら
が, 腹部外科症例について検討し, 術前危険因子とし て, 年齢, 初回手術か再手術か, ショック, 腹腔内活 染, 悪性腫瘍合併, 出血, ステロイド長期投与の有無 の 8 項目, 術前検査值の異常として, 心機能, 呼吸機 能, 肝機能, 負血, 栄盖状態, 空腹時血糖值の 6 項目 を挙げ，該当項目が4 項目までであれば手術死亡率は $0 \% ， 6$ 項目では $25 \% ， 5$ 項目では $20 \% ， 7$ 項目以上で は $100 \%$ であったと報告している．自験例に当てはめ ると，入院時には 7 項目，初回手術直前には 5 項目， 再手術直前には 3 項目となり，それぞれ手術死亡率は $100 \%, 20 \%, 0 \%$ となり，2期的手術の妥当性が裹付 けられる.

術前の検査値の補正に関しては，寺岡ら ${ }^{17}$ は，血清 BUN 值 $50 \mathrm{mg} / \mathrm{dl}$ 以下, 血清クレアチニン值 $6.0 \mathrm{mg} / \mathrm{dl}$ 以下, 血清 $\mathrm{K}$ 值 $3.0 \sim 4.5 \mathrm{mEq} / l$, ヘマトクリット值 30 $\%$ 以上, 血清タンパタ $6.5 \mathrm{~g} / \mathrm{dl}$ 以上, 血清アルプミン值 $3.5 \mathrm{~g} / \mathrm{dl}$ 以上が望ましいとしている. 自験例でも, 入院 時には血清クレアチニン，タンパク，アルプミン值が 目標に達していなかったが，初回手術，再建手術前に はいずれも目標値を達成していた。

術式の選択に関しても，待機手術では一般の手術適 応に従った術式選択が可能とする意見が多いが，緊急 手術では，消化管吻合は避ける，短時間で行う，など を考慮した術式選択が推奖されている(1618)-201，本症例 では，入院時全身状態が不良であった点から，まず， 膿瘍ドレナージを行い保存的治療を試みるのも一法で あったと考えられる。しかし，食道気管支瘦からの肺 炎の遷延が全身状態を進行性に悪化させていたと判断 し，瘦孔の遮断と膿瘍腔の確実なドレナージを行うた め，初回治療で手術的に感染源の切除を行い，再建は 2 期的に行い，良好な結果を得た。

\section{結語}

維持透析中の慢性腎不全患者で，内視鏡検查の際の 頻回の嘔吐反射による食道破裂，縦隔炎から食道気管 支瘦を形成した症例に対して，輸血，高カロリー輸液 を併用した経腸栄養で全身状態を改善し，初回手術と して積極的に感染巣の切除を行い，2 期的に再建手術 を行い救命し得た。維持透析患者の過大侵襲を伴う準 緊急手術でも，的確な栄養管理による術前全身状態の 可及的改善，手術は安全のため分割とする，などの工 夫により，積極的な根治手術を行うことが可能と考え られた。

\section{女献}

1）小松文都, 井上善雄, 楀本寛文他：透析患者の全身 
麻酔下における手術症例の桙討。西日泌 54 ： 807-811, 1992

2）賁島政邑：いわゆる特発性食道破裂の病態と治 療. 臨外 $42: 335-341,1987$

3）岩佐正人：食道癌患者の栄評価に関する臨床的 研究. 日外会誌 $84: 1031-1041,1983$

4) Saito T, Shimoda K, Kinoshita T, et al : Organ function index : a predictive marker of operative mortality based on multiple organ dysfunctions in patients with esophageal cancer. Jpn J Clin Oncol $23: 238-245,1993$

5) Boerhaave $\mathrm{H}$ : Atrocis, nec descripti prius, morbi historia. Secundum medicae artis leges conscripta. Lugduni Batavorum Bountesteniana . 1724, Derbes VJ. Mitchell RE (trans). Bull Med Libr Ass $43: 217-240.1955$

6）春口洋昭, 君川正昭, 新開真人他：透析患者の消化

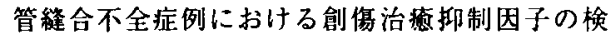
討. 腎と透析 38(別冊腎不全外科'96)：126127. 1996

7）川村博司, 飯沢 繁, 鈴木康之他：食道想室を伴っ た食道気管支瘦の1例. 日臨外医会誌 $55 ： 916$ 920. 1994

8）仲宗根恵俊, 久場睦夫, 宮城 茂他：後天性成人食 道気管支瘦の1 例. 国療沖縄医誌 $8: 64-67$, 1987

9) 吉田 毅, 阿保七三郎, 前田清貝他：Behçet 病 (不全型)に併発した食道気管支掼の 1 治験例. 秋 田医 13:501一504.1986

10）渡辺昭博, 光冨徹哉, 藤永 裕他 : 成人の食道憩室
を伴った传道気管支瘦の 1 例．松山郝字病医誌 $13: 89-93,1988$

11）酒井章次, 洪 淳一, 山本修):他：上部食道㮩室の 胸腔内破裂により生じたと思われる後天性食道気 管支搜の1例. 日臨外医会誌 $51: 975-979,1990$

12）平岡哲也，田中孝、井藤孝他：結核性食道気管 支瘦の 2 例. 岐皁市民病年報 $12: 113-116.1992$

13）上野正義，松本宗明，西和田敬他：術後，難治性食 道気管支搜を併発した特発性食道破裂の1治娩 例. 日臨外医会誌 $54: 1542-1546,1993$

14）尾崎晋一, 河野通一, 益澤桂子他：食道秝晏に食道 気管支度を合併した 1 例. 新千里病医会誌 5 ： $57-61,1994$

15）榑谷英二, 前田 清, 林部 章他：食道㮩室を伴j 後天性成人型食道気管支摟の 1 例. Gastroenterol Endosc 36：43-49, 1994

16）横田和彦, 内田久則, 杮田 章他：慢性腎不全によ る血液透析患者の腹部外科手術 (第 2 報)。日擥外 医公誌 $53: 1817$-1822,1992

17）寺岡 慧, 中川芳彦,阿岸鉄三他：腎不全患者の周 術期管理. 外科治療 $77: 318-324,1997$

18）片桐 茂, 中野 徹, 甘利正和他：透析患者におけ 万消化器手術症例の検討。山形済生館医誌 19 ： 94-99. 1994

19）上原伸一, 末永昌宏, 杉浦勇人他：慢性腎不全によ る血液透析患者に対する外科手術例の娭討．日臨 外医会誌 $57: 1079-1084,1996$

20）金 昌雄 : 透析患者の消化管手術と問題点. 腎と 透析 38(別冊 腎不全外科 '96)：68-73, 1996

\title{
A CASE OF ESOPHAGEAL-BRONCHIAL FISTURA IN A HEMODIALYSIS PATIENT WITH CHRONIC RENAL FAILURE TREATED BY OPERATION ON A TWO-STEP APPROACH
}

\author{
Yoshihiro MORIW AKI. Chikara KUNISAKI. Michio UEDA. Hirotoshi AKIYAMA. \\ Kyujiro KAMEDA and Hiroshi SHIMADA \\ Department of Surgery II, Yokohama City University School of Medicine
}

We experienced a case of esophageal-bronchial fistula in a hemodialysis patients with chronic renal falure who was saved by operation on a two-step approach. A 55-year-old woman on hemodialysis from 1990 was addmitted to the department for refractory esophageal-bronchial fistura on March 7, 1995. She had been treated conservatively under the diagnosis of esophageal rupture and mediastinitis after upper gastrointestinal fiberscopy. Although a huge cavity and a fistula to the left bronchiole $\left(\mathrm{B}^{6}\right.$ and $\left.\mathrm{B}^{10}\right)$ were recognized, severe inflammation, malnutrition, low cardiac function and low respiratory function prohibited from aggressive surgery. Therefore, we first tried to improve her general condition by enteral diet assisted with parental nutrition and transfusion. At operation, a two-step approach was adopted. The first operation was performed on September 19,1995, including esophagectomy, esophagostomy, gastrostomy and closure of the fistura by suture and bond. Sixty-three days lator, the second operation was performed including reconstruction with gastric tube through the retrosternal routs. Postoperative course was uneventful. She was discharged from the hospital 37 days after the second operation. 